\title{
Dexamethasone Depletes $\gamma \delta$ T Cells and Alters the Activation State and Responsiveness of Bovine Peripheral Blood Lymphocyte Subpopulations ${ }^{1}$
}

\author{
C. Menge ${ }^{\star 2}$ and E. A. Dean-Nystrom† \\ *Institute for Hygiene and Infectious Diseases of Animals, Justus-Liebig-University, D-35392 Giessen, Germany \\ †Pre-Harvest Food Safety and Enteric Diseases Research Unit, National Animal Disease Center, USDA Agricultural Research Service, \\ Ames, IA 50010
}

\begin{abstract}
Administration of dexamethasone (DEX) to cattle is commonly used in models of stress-induced effects on host defense, including models investigating interactions of microorganisms with their host. Much less is known about the effects of DEX on the adaptive immune response in cattle compared with other species. The objective of the present study was to characterize subsets of circulating lymphocytes in calves before and $48 \mathrm{~h}$ after the onset of parenteral DEX treatment. Treatment significantly reduced the overall percentage of circulating lymphocytes and disproportionately depleted the population of $\gamma \delta \mathrm{TCR}^{+} / \mathrm{CD} 8 \alpha^{-}$cells. Analysis within the $\mathrm{CD} 8 \alpha^{+}$population of $\mathrm{T}$ cells revealed that DEX treatment also reduced the $\mathrm{CD} 8 \alpha^{\text {low }}$ subset of $\gamma \delta \mathrm{T}$ cells coexpressing the activation marker ACT- $2^{+}$. By contrast, DEX treatment did not affect the percentage of CD $8 \alpha^{\text {low }} /$ $\mathrm{CD}^{+} 5^{+}$cells, indicating that cells with a special activation state were affected. Dexamethasone treatment reduced the number of $\gamma \delta \mathrm{T}$ cells but increased the percentages of $\mathrm{CD} 14^{+}$monocytes and activated $\mathrm{CD} 25^{+}$cells (both $\mathrm{CD}^{-}$and $\mathrm{CD} 4^{+}$) in peripheral blood mononuclear cell (PBMC) preparations. Although DEX treatment reduced the overall proliferative capacity of PBMC, it enhanced the relative number of proliferating $\mathrm{CD} 4^{+}$ lymphocytes. Lower levels of mRNA for several Thprototype cytokines (IL-2, IFN- $\beta$, IL-4, transforming growth factor- $\beta$ ) were detected in short-term PBMC cultures established from DEX-treated calves compared with PBMC cultures from control calves; the amount of $i l-10$ transcripts, however, was unaffected. Results of the study reported here clearly show that DEX treat-
\end{abstract}

\footnotetext{
Received December 11, 2007.

Accepted February 14, 2008.

${ }^{1}$ Mention of trade names or commercial products in this article is solely for the purpose of providing specific information and does not imply recommendation or endorsement by the US Department of Agriculture.

${ }^{2}$ Corresponding author: christian.menge@vetmed.uni-giessen.de
}

ment does not uniformly suppress the bovine immune system but has differential effects on lymphocyte subpopulations and functions. This information must be considered when using DEX treatment as a bovine stress model.

Key words: dexamethasone, in vivo, lymphocyte, cattle

\section{INTRODUCTION}

Glucocorticosteroids (GC) are widely used in buiatrics to limit inflammatory processes that otherwise would significantly contribute to pathology, prolong recovery time, and compromise animal welfare (Sustronck et al., 1997; Moire et al., 2002). Despite conflicting reports on their immunosuppressive action, GC are also administered to induce parturition (Mansell et al., 2006) and to treat parturition-associated metabolic disorders (Thanasak et al., 2004). In experimental settings, the synthetic compound dexamethasone (DEX), serving as a GC prototype, has been administered to simulate stress-induced immunosuppression in cattle (Estrada et al., 1999; Lippolis et al., 2006) and to exacerbate infectious processes, such as to reactivate bovine herpesvirus type 1 infections (Vogel et al., 2004) and to induce or prolong shedding of Salmonella (Lomborg et al., 2007), Listeria (Wesley et al., 1989), Staphylococcus aureus (Burton and Kehrli, 1995), and shigatoxigenic Escherichia coli (Stoffregen et al., 2004).

Studies aimed at elucidating the effects of DEX on the bovine immune system at the molecular level have focused primarily on cells of the innate part of the system (i.e., polymorphonuclear neutrophils). Burton and colleagues discovered that DEX down-regulates CD18 and CD62L adhesion molecules on blood neutrophils in vivo by acting at the pretranslational level (Burton et al., 1995; Weber et al., 2001; Weber et al., 2004). Lippolis et al. (2006) recently provided a comprehensive list of differentially expressed proteins in neutrophils from DEX-treated dairy cows. In functional terms, neutrophils from DEX-treated cattle display enhanced ran- 
dom migration but impaired bacterial ingestion, impaired oxidative burst activity, and impaired antibodydependent, cell-mediated cytotoxicity (Roth and Kaeberle, 1981).

Although a multitude of effects of DEX on parameters of the adaptive immune response have been described in humans (Belvisi, 2004; Georas, 2004; Barnes, 2006), the respective knowledge for cattle is sparse. Several studies have shown that DEX administration in vivo reduces the mitogenic responsiveness of bovine lymphocytes in vitro (Pruett et al., 1987; Roth et al., 1990; Oldham and Howard, 1992). The inability of some investigators using a different experimental design to detect such an effect led Pruett et al. (1987) to suggest that the proliferation-suppressing effects of DEX are dependent on dosage and application scheme (Roth and Kaeberle, 1985; Pruett et al., 1987; Oldham and Howard, 1992). Nonnecke et al. (1997) found that DEX administration led to a marked reduction in the in vitro secretion of IFN- $\gamma$ and IgM by mitogen-stimulated lymphocytes. Dexamethasone sensitizes the $\beta$-adrenergic receptor system in bovine lymphocytes in vivo (Abraham et al., 2004). Although DEX has been shown to reactivate bovine rhinotracheitis virus infections (Pastoret et al., 1980; Ohmann et al., 1987), the consequence of DEX effects on lymphocyte functions in the context of an immune response is not yet clear.

A better understanding of the immunological effects of DEX at the molecular level is crucial for improving therapeutic regimens in cattle. The generation of a straightforward design for functional studies strongly relies, however, on comprehensive information on the composition of circulating lymphocytes in treated animals. Evidence exists that DEX administration not only depresses the total number of circulating lymphocytes, but also affects various lymphocyte subsets differentially, thereby also altering the composition of peripheral blood mononuclear cell (PBMC) preparations. In turn, the cellular composition correlates with the total IFN- $\gamma$ protein secretion in vitro (Nonnecke et al., 1997). Present knowledge of the impact of DEX on lymphocyte composition is inconsistent and restricted to the definition and quantification of the major subsets; although a DEX-induced reduction in the percentage of $\mathrm{WC}^{+}$ cells (i.e., the majority of $\gamma \delta$ cells in bovine blood) has been reported repeatedly (Burton and Kehrli, 1996; Nonnecke et al., 1997; Saama et al., 2004), conflicting data are available regarding $\mathrm{B}$ cells and $\mathrm{CD} 8^{+} \mathrm{T}$ cells (Oldham and Howard, 1992; Anderson et al., 1999). Moreover, down-regulated major histocompatibility complex-II (MHC-II) expression (Nonnecke et al., 1997) and increased percentages of CD25 ${ }^{+}$cells (Anderson et al., 1999) point to subtle changes in the activation state of lymphocytes in DEX-treated cattle in vivo. To test the hypothesis that DEX treatment differentially affects lymphocyte subsets in addition to $\gamma \delta$ T cells, we characterized in more detail circulating lymphocytes in DEXtreated calves. On the basis of the assumption that DEX-induced changes can be detected most reliably by analysis of leukocytes not subject to a separation procedure, studies were performed with whole blood, and values were compared with values obtained with isolated PBMC. Functional assays were included to provide insight into the consequences of the altered activation state of the cells.

\section{MATERIALS AND METHODS}

\section{Animals and Treatment}

Twelve weaned (10 to 15 wk old) Jersey bull calves were involved in this study. Calves purchased from local sources were acclimated to diet (two-thirds grain and one-third hay) and housing conditions (biological safety level 2 containment barns) at the National Animal Disease Center (NADC) in Ames, Iowa, for 3 wk before treatment. Animal care was in accordance with NADC Animal Care and Use Committee requirements. Calves were tested in 6 separate experiments, 2 calves per experiment. Six calves were treated twice with DEX $(0.25 \mathrm{mg} / \mathrm{kg}$ administered i.v. on 2 consecutive days); 6 control calves were not treated, but were sampled similarly to treated calves. Peripheral venous blood samples were obtained from each calf on d 0 , immediately before the first treatment pre DEX or precontrol (pre CON)] and on d 2, at $48 \mathrm{~h}$ after the onset of treatment (post DEX or post CON). Ethylenediaminotetraacetate blood samples (collected in $\mathrm{K}_{3}$-EDTA Vacutainer tubes, Becton Dickinson, Mountain View, CA) were used for total and differential blood counts and immunophenotyping of leukocytes. Citrated blood samples [96 mL of venous blood collected in a syringe containing $24 \mathrm{~mL}$ of $3.8 \%$ sodium citrate solution (wt/vol)] were used for preparation of PBMC.

\section{Total and Differential Leukocyte Counts}

Numbers of white blood cells were counted in EDTA blood samples with an electronic cell counter (Coulter Counter, BeckmanCoulter, Miami, FL). Differential cell counts were microscopically determined after staining blood smears with Accustain Wright stain (Sigma-Aldrich, St. Louis, MO).

\section{Immunophenotyping of Lymphocytes in Whole Blood (Circulating Lymphocytes)}

Lymphocytes in peripheral venous blood samples were characterized by dual-staining flow cytometry 
Table 1. Specificity, isotype, and working dilution of antibodies used for immunophenotyping

\begin{tabular}{|c|c|c|c|c|}
\hline Application or antigen ${ }^{1}$ & Clone no. & Isotype & $\begin{array}{l}\text { Working } \\
\text { dilution } \\
\text { ( } \mu \mathrm{L} / \mathrm{mL})\end{array}$ & Source $^{2}$ \\
\hline \multicolumn{5}{|c|}{ Immunophenotyping of circulating lymphocytes and PBMC } \\
\hline CD2 & BAQ95A & ms IgG1 & 7 & VMRD \\
\hline CD3 & MM1A & ms IgG1 & 7 & VMRD \\
\hline CD4 & GC50A1 & ms IgM & 14 & VMRD \\
\hline CD5 & B29A & ms IgG2a & 14 & VMRD \\
\hline $\operatorname{CD} 8 \alpha$ & BAQ111A & ms IgM & 14 & VMRD \\
\hline $\mathrm{CD} 8 \beta$ & BAT82A & ms IgG1 & 7 & VMRD \\
\hline CD14 & CAM36A & ms IgG1 & 7 & VMRD \\
\hline CD21 & BAQ15A & ms IgM & 7 & VMRD \\
\hline CD25 & CACT116A & ms IgG1 & 20 & VMRD \\
\hline CD45RO & GC42A1 & ms IgG1 & 10 & VMRD \\
\hline $\mathrm{N} 24(\gamma \delta \mathrm{TCR})$ & GB21A & ms IgG2b & 10 & VMRD \\
\hline ACT-2 & CACT26A & ms IgG1 & 7 & VMRD \\
\hline Anti-ms IgM FITC & & & 6.4 & SBA \\
\hline Anti-ms IgG1 R-PE & & & 3.2 & SBA \\
\hline Anti-ms IgG2a R-PE & & & 3.2 & SBA \\
\hline Anti-ms IgG2b FITC & & & 6.4 & SBA \\
\hline Anti-ms IgG2b R-PE & & & 3.2 & SBA \\
\hline \multicolumn{5}{|c|}{ Immunophenotyping of long-term-cultured PBMC } \\
\hline CD4 & CACT138A & ms IgG1 & 10 & VMRD \\
\hline $\mathrm{CD} 8 \alpha$ & CACT80C & ms IgG1 & 10 & VMRD \\
\hline $\mathrm{CD} 8 \beta$ & BAT82A & ms IgG1 & 7 & VMRD \\
\hline CD21 & $\mathrm{CC} 21$ & ms IgG1 & 7 & Serotec \\
\hline CD25 & CACT116A & ms IgG1 & 20 & VMRD \\
\hline $\mathrm{N} 24(\gamma \delta \mathrm{TCR})$ & GB21A & ms IgG2b & 10 & VMRD \\
\hline ACT-2 & CACT26A & ms IgG1 & 7 & VMRD \\
\hline Anti-ms IgG1 PerCP & & & 64 & SBA \\
\hline Anti-ms IgG2 PerCP & & & 64 & SBA \\
\hline
\end{tabular}

\footnotetext{
${ }^{1} \mathrm{PBMC}=$ peripheral blood mononuclear cells; FITC = fluorescein isothiocyanate; R-PE = R-phycoerythrin; PerCP = peridinin-chlorophyll-protein complex.

${ }^{2}$ VMRD, Pullman, WA; SBA (Southern Biotech Associates), Birmingham, AL; Serotec, Raleigh, NC.
}

analyses. Each blood sample was tested in duplicate with each antibody combination. Immunolabeling assays were performed on ice. Per well of a 96-well plate (U-shaped), $50 \mu \mathrm{L}$ of EDTA peripheral venous blood was added to $100 \mu \mathrm{L}$ of precooled $\left(4^{\circ} \mathrm{C}\right)$ solutions of the primary antibodies $[50 \mu \mathrm{L}$ of working solution of each of 2 primary antibodies (Table 1 ) diluted in PBS supplemented with $1 \%$ (wt/vol) of BSA and $0.01 \%$ (wt/vol) $\mathrm{NaN}_{3}$; referred to as PBS-BSA-azide]. Ten microliters of 4,6-diamidino-2-phenylindole, dihydrochloride (DAPI) solution (10 $\mu \mathrm{g} / \mathrm{mL}$ in PBS-BSA-azide) was added to label cells with altered membrane integrity. After 15 min of incubation in the dark, plates were centrifuged $(400 \times g ; 2 \mathrm{~min})$ and supernatants were removed by inverted flicking of the plate. To remove the erythrocytes by hypotonic lysis, $200 \mu \mathrm{L}$ of distilled water was added to the wells, followed $5 \mathrm{~s}$ later by addition of 20 $\mu \mathrm{L}$ of a 10 -fold concentrated PBS solution. Cells were pelleted by centrifugation as described above and resuspended in the appropriate secondary antibodies $[50 \mu \mathrm{L}$ of working solution of each of 2 secondary antibodies (Table 1)]. After 15 min of incubation, cells were washed by centrifugation and resuspended in $200 \mu \mathrm{L}$ of PBSBSA-azide and $200 \mu \mathrm{L}$ of FACSlyse solution (BD Biosci- ences, San Jose, CA), consecutively. Flow cytometric analysis was performed on an LSR I flow cytometer (BD Biosciences) acquiring 10,000 events. Dead cells [i.e., events with a high DAPI fluorescence (FL-5H) signal] were excluded from further analysis by creating a gate defining less than $2 \%$ of the cells positive in a negative control sample (prepared without DAPI). Data were analyzed with FCS Express version 2 software (DeNovo software, Thornhill, Canada) by setting an analysis gate surrounding the lymphocyte population as defined by its forward vs. sideward scatter characteristics. Events within the whole-blood lymphocyte gate are referred to as circulating lymphocytes throughout this manuscript.

\section{Immunophenotyping of PBMC}

Bovine $\mathrm{PBMC}$ were isolated by density centrifugation with Ficoll-Paque Plus (Amersham Biosciences, Freiburg, Germany), as described previously (Menge et al., 1999). Immunophenotyping of PBMC $\left(1 \times 10^{5}\right.$ cells per sample) was performed as described above for circulating lymphocytes with the following exceptions: the hypotonic lysis step was replaced by a washing step with 
PBS-BSA-azide and a different panel of antibodies was used to label PBMC (Table 1). Data obtained for 10,000 events were analyzed, with dead cells being excluded by means of their high DAPI fluorescence signal.

\section{Determination of the Proliferative Capacity of PBMC Subpopulations (Long-Term-Cultured PBMC)}

For analysis of the proliferative capacity of PBMC, 5 $\times 10^{7}$ cells in $5 \mathrm{~mL}$ of RPMI 1640 devoid of serum were pelleted by centrifugation $(400 \times g, 5 \mathrm{~min})$ in $50-\mathrm{mL}$ conical centrifugation tubes. Cells were resuspended in $2.5 \mathrm{~mL}$ of the diluent provided by the test kit (PKH67 Green Fluorescent Cell Linker Kit, Sigma-Aldrich) and rapidly transferred to $2.5 \mathrm{~mL}$ of a freshly prepared 2 fold solution of PKH67 $\left(4 \times 10^{-6} M\right.$ in the diluent) in a separate $50-\mathrm{mL}$ tube. After $5 \mathrm{~min}$ of incubation at $25^{\circ} \mathrm{C}$, $5 \mathrm{~mL}$ of fetal bovine serum (Invitrogen, Carlsbad, CA) was added for another minute, followed by addition of $10 \mathrm{~mL}$ of PBMC medium [RPMI 1640 with stabilized glutamine (Invitrogen), 10\% (vol/vol) fetal bovine serum, $3 \mu M$ mercaptoethanol (Sigma-Aldrich), $100 \mathrm{IU}$ of penicillin $/ \mathrm{mL}$, and $100 \mu \mathrm{g} / \mathrm{mL}$ of streptomycin (Invitrogen)]. Cells were washed twice by centrifugation $\left(400 \times g, 5 \mathrm{~min}, 25^{\circ} \mathrm{C}\right)$ with $10 \mathrm{~mL}$ of PBMC medium. Peripheral blood mononuclear cell suspensions were finally adjusted to $2.5 \times 10^{5}$ cells $/ 150 \mu \mathrm{L}$ in PBMC medium supplemented with $5 \mu \mathrm{g} / \mathrm{mL}$ of the mitogen phytohemagglutinin-P (Sigma-Aldrich) and incubated in 96well plates for $96 \mathrm{~h}$ at $37^{\circ} \mathrm{C}, 5 \% \mathrm{CO}_{2}$, and $95 \%$ humidity. Cultures of PKH67-labeled cells without mitogen were included as low-proliferation controls in each of the experiments. At the end of the cultivation, cell suspensions were removed from the wells and transferred to 96-well plates (U-shaped). All subsequent steps were performed at $4^{\circ} \mathrm{C}$. Plates were centrifuged $(400 \times g ; 2$ $\mathrm{min}$ ) and supernatants were removed by inverted flicking of the plate. Primary antibodies $(50 \mu \mathrm{L}$ of working solution diluted in PBS-BSA-azide; Table 1) were added together with $10 \mu \mathrm{L}$ of DAPI solution. After $15 \mathrm{~min}$ of incubation in the dark, plates were centrifuged $(400 \times$ g; 2 min) and supernatants were removed by inverted flicking of the plate. Cells were resuspended in the appropriate secondary antibodies (50 $\mu \mathrm{L}$ of working solution; Table 1), incubated 15 min and washed with PBSBSA-azide, resuspended in FACSlyse solution, and analyzed by flow cytometry analysis as described above. Populations of enlarged lymphoblast cells and untransformed nonblast cells were defined according to their light-scattering characteristics as described previously (Menge et al., 2001). Alternatively, all events acquired (i.e., irrespective of their light-scattering characteristics) were analyzed with respect to their FL-1H (PKH67) and FL-5H (DAPI) fluorescence signals.
Events with a reduced FL-1H signal, as compared with PKH67-labeled cells without mitogen, were designated proliferated cells; cells exhibiting an unaltered FL-1H signal were designated resting cells. Cells were further divided as viable cells and dead cells based on their FL$5 \mathrm{H}$ signal, as described for the analysis of circulating lymphocytes. In a subsequent analysis step, a gate was created embracing all (i.e., viable and dead) proliferated cells, and cells within that gate were analyzed for CD markers.

\section{Determination of Transcription of Selected Cytokines in Short-Term-Cultured PBMC}

Freshly prepared PBMC were seeded in 6-well cell culture plates in PBMC medium $\left(2 \times 10^{7}\right.$ in $\left.9 \mathrm{~mL}\right)$ supplemented with $2.5 \mu \mathrm{g} / \mathrm{mL}$ of phytohemagglutinin-P (Sigma-Aldrich). Peripheral blood mononuclear cells were incubated for $7.5 \mathrm{~h}$ at $37^{\circ} \mathrm{C}$ in $5 \% \mathrm{CO}_{2}$ and $95 \%$ humidity, and then resuspended, transferred to $50-\mathrm{mL}$ centrifugation tubes, washed with PBS $(202 \times g, 7 \mathrm{~min}$, $20^{\circ} \mathrm{C}$ ), and lysed in $600 \mu \mathrm{L}$ of RLT buffer (RNeasy Mini Kit, Qiagen, Valencia, CA) supplemented with 1\% (vol/ vol) $\beta$-mercaptoethanol and stored at $-70^{\circ} \mathrm{C}$. Preparation of mRNA, reverse transcription, and cytokine-specific real-time PCR were performed as described by Moussay et al. (2006) by using previously described primers and probes specific for mRNA encoding IL-2, IL-4, IL-8, IFN- $\gamma$, transforming growth factor- $\beta$ (TGF$\boldsymbol{\beta})$, and tumor necrosis factor- $\alpha$ (TNF- $\alpha$ ) (Leutenegger et al., 2000; Moussay et al., 2006). Polymerase chain reaction amplification was performed on an automated fluorometer (ABI Prism 5700 Sequence Detection System, Applied Biosystems, Darmstadt, Germany) using 96-well optical plates. Quantities are reported as amounts of specific mRNA relative to the amount of mRNA for the housekeeping gene GAPDH in the same sample (n-fold the amount of GAPDH transcripts in the same sample).

\section{Statistical Analysis}

Data were analyzed statistically by 2 -way ANOVA with repeated measures with respect to the variable sampling time by using BMDP/Dynamic software (Dixon, 1993). Performing ANOVA requires normally distributed data. Because all variables were nonnegative, normality was investigated for the data set by evaluating the coefficients of variation. Because normality was not found to be given for the data set analyzed herein, data were transformed by arcsine transformation (Sheskin, 2007; percentages of lymphocyte subsets) and logarithmic transformation (fluorescence intensities and relative amounts of mRNA). In all anal- 
yses, a significance level of $\alpha=0.05$ was applied (levels of probability are indicated as follows: $* P \leq 0.05$; ** $P \leq$ 0.01 ; $* * * P \leq 0.001)$. Results were considered not significant if $P>0.05$; in this case, the results of the statistical analyses were omitted from the figures.

\section{RESULTS}

\section{Effects of DEX Treatment on Blood Leukocyte Counts}

Dexamethasone treatment was associated with blood leukocytosis and neutrophilia. At $2 \mathrm{~d}$ after the first DEX treatment, calves showed a striking increase in white blood cell counts, from $11.5 \pm 3.2$ (mean $\pm \mathrm{SD}$; $\mathrm{n}=6$ calves) to $20.8 \pm 5.2 \times 10^{3}$ leukocytes $/ \mu \mathrm{L}$. At the same time, calves in the control group exhibited a slight decline in leukocyte counts, from $12.6 \pm 2.2$ to $10.3 \pm 1.9$ $\times 10^{3}$ leukocytes $/ \mu \mathrm{L}$ ( $\mathrm{n}=6$ calves). The percentages of lymphocytes, segmented neutrophils, and monocytes were $71.5 \pm 13.4 \%, 23.6 \pm 13.0 \%$, and $2.2 \pm 1.2 \%$ (mean $\pm \mathrm{SD} ; \mathrm{n}=6$ calves), respectively, before DEX treatment; and $22.2 \pm 4.3 \%, 71.0 \pm 7.7 \%$, and $6.8 \pm 6.5 \%$, respectively, after the onset of treatment. Dexamethasone treatment also reduced the absolute numbers of peripheral lymphocytes from $8.0 \pm 1.8$ to $4.6 \pm 1.1 \times 10^{3} / \mu \mathrm{L}$. Leukocyte compositions in control calves were not affected by repeated blood samplings $(74.5 \pm 9.0 \%$ vs. 76.5 $\pm 6.3 \%$ for lymphocytes, $20.7 \pm 8.8 \%$ vs. $17.7 \pm 7.3 \%$ for segmented neutrophils, and $2.5 \pm 1.8 \%$ vs. $3.5 \pm 1.5 \%$ for monocytes; $\mathrm{n}=6$ calves).

\section{Definition of Circulating Lymphocyte Subpopulations}

Dual-color flow cytometry was applied to quantify different subpopulations of circulating lymphocytes. Special emphasis was placed on the separate analysis and quantification of lymphocyte subsets expressing high and low numbers of CD $8 \alpha$ molecules on their surface (designated CD8 $8 \alpha^{\text {high }}$ and $\mathrm{CD} 8 \alpha^{\text {low }}$ lymphocytes). Both $\mathrm{CD} 8 \alpha^{+}$subsets were $\mathrm{CD}^{+}$(not shown) but differentially expressed CD5 (Figure 1): CD8 $\alpha^{\text {high }}$ cells expressed intermediate levels of CD5, and most $\mathrm{CD} 8 \alpha^{\text {low }}$ lymphocytes were $\mathrm{CD} 5^{\text {low }}$. The majority of $\mathrm{CD} 8 \alpha^{\text {high }}$ cells, but only a minority of CD8 $\alpha^{\text {low }}$ cells, coexpressed CD2. Most of the CD8 $\alpha^{\text {low }}$ cells, but only a few CD8 $\alpha^{\text {high }}$ cells, coexpressed $\gamma \delta$ TCR. Most CD $8 \alpha^{\text {high }}$ cells, a small subpopulation of $\gamma \delta \mathrm{TCR}^{+}$lymphocytes, and some $\mathrm{CD} 8 \alpha^{\text {low }}$ lymphocytes coexpressed CD8 $\beta$.

\section{Effect of DEX Treatment on the Composition of Circulating Lymphocytes}

The major subset composition of circulating lymphocytes in control calves was unaffected by repeated blood sampling (Figure 2). Dexamethasone treatment not only resulted in an overall decrease in lymphocyte numbers, but also particularly depleted certain lymphocyte subsets. Treatment led to a relative reduction of $\mathrm{CD}^{+} /$ $\mathrm{CD} 8 \alpha^{-}$and $\mathrm{CD}^{+} / \mathrm{CD}^{-}$lymphocytes in the DEX-treated group, but not in the control group $[P$-value for the combined impact of group and sampling time $\left(\boldsymbol{P}_{\text {group/ }}\right.$ time $) \leq 0.001$ in both instances; Figure 2A]. This reduction particularly resulted from a disproportionate depletion of $\gamma \delta \mathrm{TCR}^{+}$cells that coexpressed neither CD8 $\alpha$ nor $\operatorname{CD} 8 \beta\left(\boldsymbol{P}_{\text {group/time }} \leq 0.001\right.$ in both instances; Figure 2B). Notably, a relative reduction was also observed for CD $8 \alpha^{+} \gamma \delta \mathrm{T}$ cells $\left(P_{\text {group } / \text { time }} \leq 0.05\right)$ and $\mathrm{CD} 8 \beta^{+}$

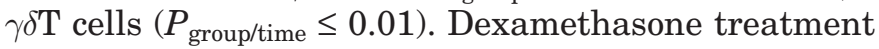
induced a relative increase in $\mathrm{CD}^{-} \mathrm{B}$ cells $\left(\mathrm{CD} 21^{+} /\right.$ $\mathrm{CD5}^{-} ; P_{\text {group/time }} \leq 0.01$ ).

Dexamethasone-induced changes included a relative reduction of memory and activated lymphocytes $\left(\mathrm{CD} 45 \mathrm{RO}^{+}, \mathrm{ACT}^{-} 2^{+}\right.$, and $\mathrm{CD} 25^{+}$) that were $\mathrm{CD} 4^{-}$(Figure 3A). Dexamethasone treatment affected the expression of activation markers by $\mathrm{CD} 8 \alpha^{+}$lymphocytes, but differently in CD8 $\alpha^{\text {low }}$ and CD8 $\alpha^{\text {high }}$ cells (Figure 3B): DEX depleted $\mathrm{ACT}-2^{+} / \mathrm{CD} 8 \alpha^{\text {low }}$ lymphocytes but increased the portion of $\mathrm{CD} 25^{+} / \mathrm{CD} 8 \alpha^{\text {high }}$ cells. The percentage of $\mathrm{CD} 25^{+} / \mathrm{CD} 8 \alpha^{\text {low }}$ cells remained constant, but DEX notably increased CD25 surface expression by this subset (Figure 3C).

\section{Effect of DEX Treatment on the Composition and Proliferative Capacity of PBMC}

Peripheral blood mononuclear cell preparations obtained from both groups of calves at both sampling times contained comparable portions of $\mathrm{CD}^{+}$and $\mathrm{CD} \alpha^{+} / \gamma \delta \mathrm{TCR}^{-}$(Figure 4). Dexamethasone treatment reduced the portion of $\gamma \delta \mathrm{T}$ cells in PBMC preparations: the percentage of $\gamma \delta \mathrm{T}$ cells lacking CD8 $\alpha$ expression was reduced by half, and a similar tendency was also observed for $\mathrm{CD} 8 \alpha^{+} \gamma \delta \mathrm{T}$ lymphocytes. Of note, the percentage of CD25-expressing cells was markedly increased in the $\mathrm{CD}^{-}$and in the $\mathrm{CD} 4^{+}$lymphocyte subsets. Peripheral blood mononuclear cells from DEXtreated calves consisted of significantly more monocytes (i.e., CD14 ${ }^{+}$cells) compared with PBMC isolated before treatment or from control animals.

Dexamethasone affected the proliferative capacity of PBMC. After $96 \mathrm{~h}$ of mitogenic stimulation in vitro, PBMC cultures obtained from calves after DEX treatment contained $59.1 \pm 13.5 \%$ (mean $\pm \mathrm{SD} ; \mathrm{n}=6$ ) cells that had proliferated compared with $69.2 \pm 5.1 \%$ in PBMC cultures prepared from the same animals before DEX treatment. As shown in Figure 5, DEX treatment particularly led to an increase in cells that underwent cellular death before beginning to proliferate (dead rest- 

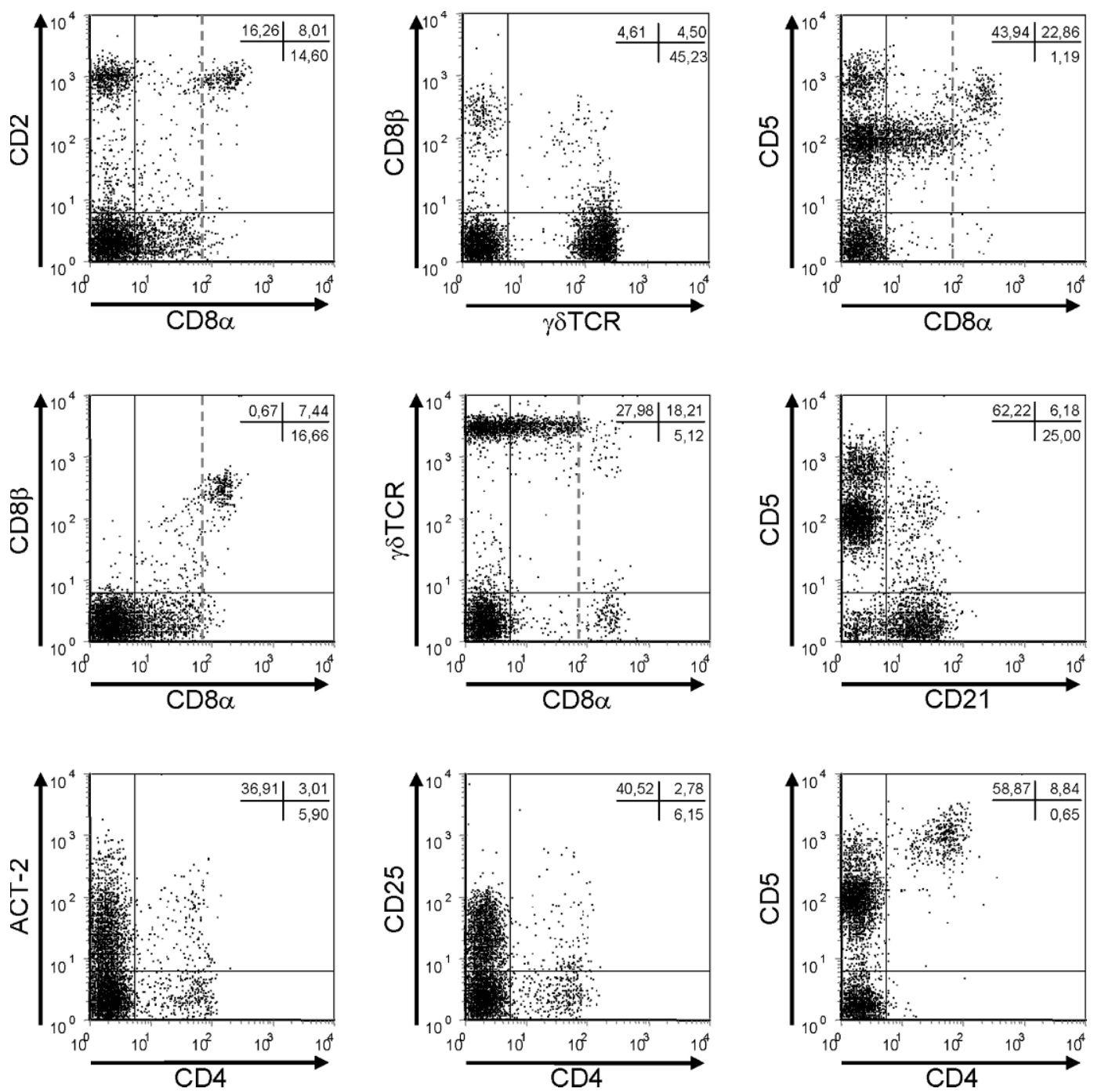

Figure 1. Representative flow cytometry dot plots illustrating the antigen-expression patterns of bovine circulating lymphocytes in vivo. Dot plots depict cells of the lymphocyte region in the forward vs. sideward scatter plot from a representative blood sample. Percentages of cells positive for one or both of the antigens are indicated in the upper right corner of each dot plot. Dashed lines are indicating the threshold applied to distinguish between $\mathrm{CD} 8 \alpha^{\text {low }}$ and $\mathrm{CD} 8 \alpha^{\text {high }}$ cells where appropriate.

ing cells), to higher numbers of PBMC that transformed to blast cells, and to slightly increased numbers of cells exhibiting morphological patterns indicative of cell death (subvital cells).

The majority of cells proliferating (dead proliferated cells plus viable proliferated cells in Figure 5) were $\gamma \delta \mathrm{T}$ cells. Although PBMC preparations from DEX-treated calves contained fewer $\gamma \delta$ T cells before cultivation, the portion of proliferated $\gamma \delta$ T cells was similar in all PBMC cultures from DEX-treated calves $(59.4 \pm 11.7 \%$ vs. 66.2 $\pm 22.5 \%$ in cultures initiated before DEX treatment; $\mathrm{n}=$ 6 ) and nontreated calves $(73.5 \pm 8.2 \%$ vs. $81.3+5.8 \%$, PBMC from pre and post CON sampling time, respectively; $P_{\text {group/time }}>0.05$ ). Peripheral blood mononuclear cell cultures from DEX-treated calves contained significantly more proliferated $\mathrm{CD} 4^{+}$cells $(17.5 \pm 11.1 \%$; $\mathrm{n}=6$ ) than cultures initiated before treatment (5.6 \pm $3.9 \%)$ or cultures from nontreated calves $(5.7 \pm 3.1 \%$ vs. $4.4 \pm 0.9 \%, \mathrm{PBMC}$ from pre and post CON sampling time, respectively; $P_{\text {group/time }} \leq 0.05$ ).

\section{Effect of DEX Treatment on the Amount of mRNA for Selected Cytokines in PBMC}

Following short-term culture in the presence of a mitogen, lower amounts of mRNA specific for Th1 prototype cytokines (IL- 2, IFN- $\gamma$ ), the Th2 cytokine IL- 4 , the Th3 cytokine TGF- $\beta$, and the proinflammatory TNF- $\alpha$ 


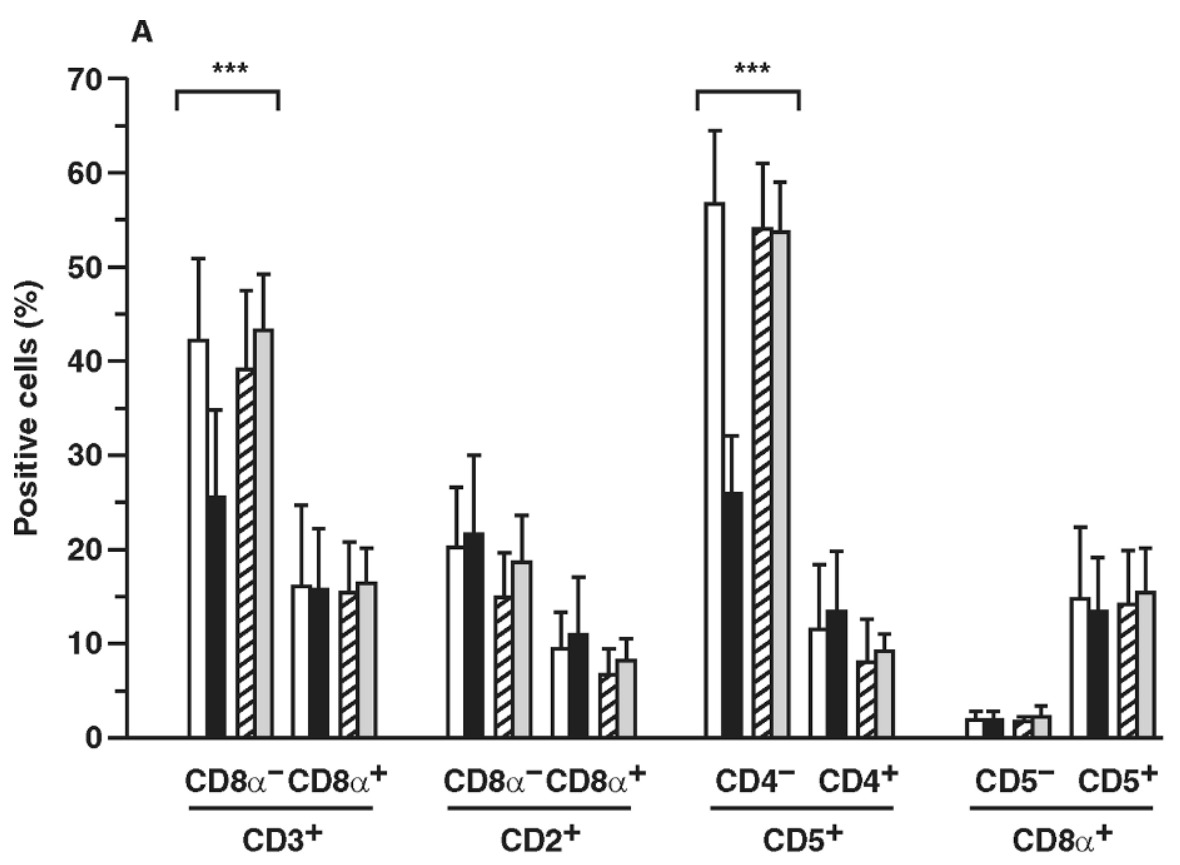

B

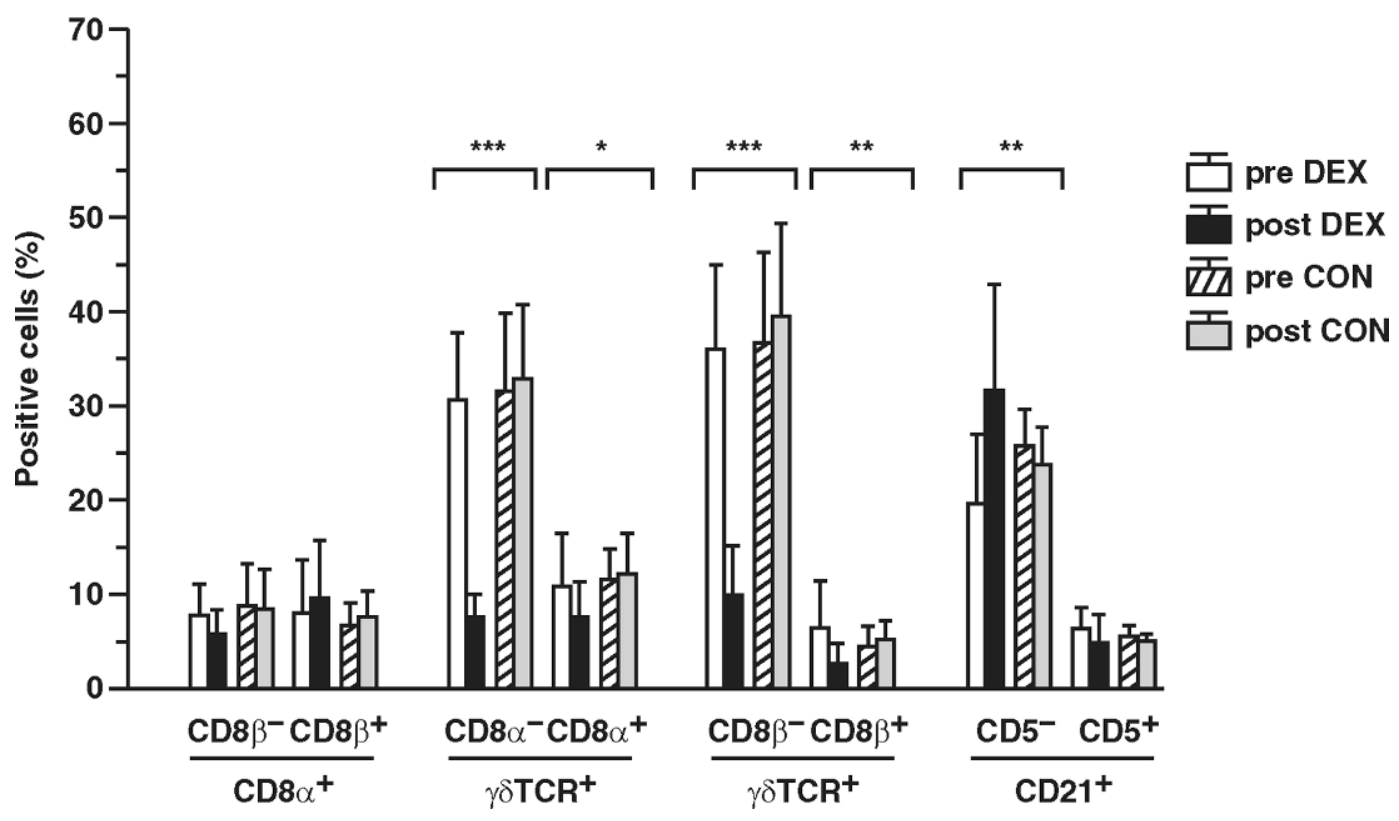

Figure 2. Influence of dexamethasone (DEX) treatment in vivo on the major subset composition of circulating lymphocytes in calves. Cells were analyzed as in Figure 1. Percentages of cells in the lymphocyte gate are depicted. Values represent mean \pm SD of determinations from all animals per group/sampling time [each blood sample examined in duplicate; treatment group ( $\mathrm{n}=4$ to 6 calves): sampling before DEX treatment (pre DEX), sampling $48 \mathrm{~h}$ after the onset of DEX treatment (post DEX); nontreated group ( $\mathrm{n}=6 \mathrm{calves}$ ): first sampling (pre $\mathrm{CON})$ and second sampling $48 \mathrm{~h}$ later (post CON)]. Significances for the combined impact of group and sampling time $\left(P_{\text {group/time }}\right)$ on a given parameter are indicated by asterisks: $* P \leq 0.05 ; * * P \leq 0.01 ; * * * \leq 0.001$.

were detected in PBMC prepared from DEX-treated calves compared with PBMC from the same animals before treatment (Figure 6). By contrast, the amounts of IL-8-specific mRNA were slightly increased following DEX treatment, whereas the opposite effect could be observed in the control group comparing pre and post CON PBMC cultures. Interestingly, the amount of IL10-specific mRNA was found to be higher in PBMC prepared from the second blood sample in both groups of calves. 

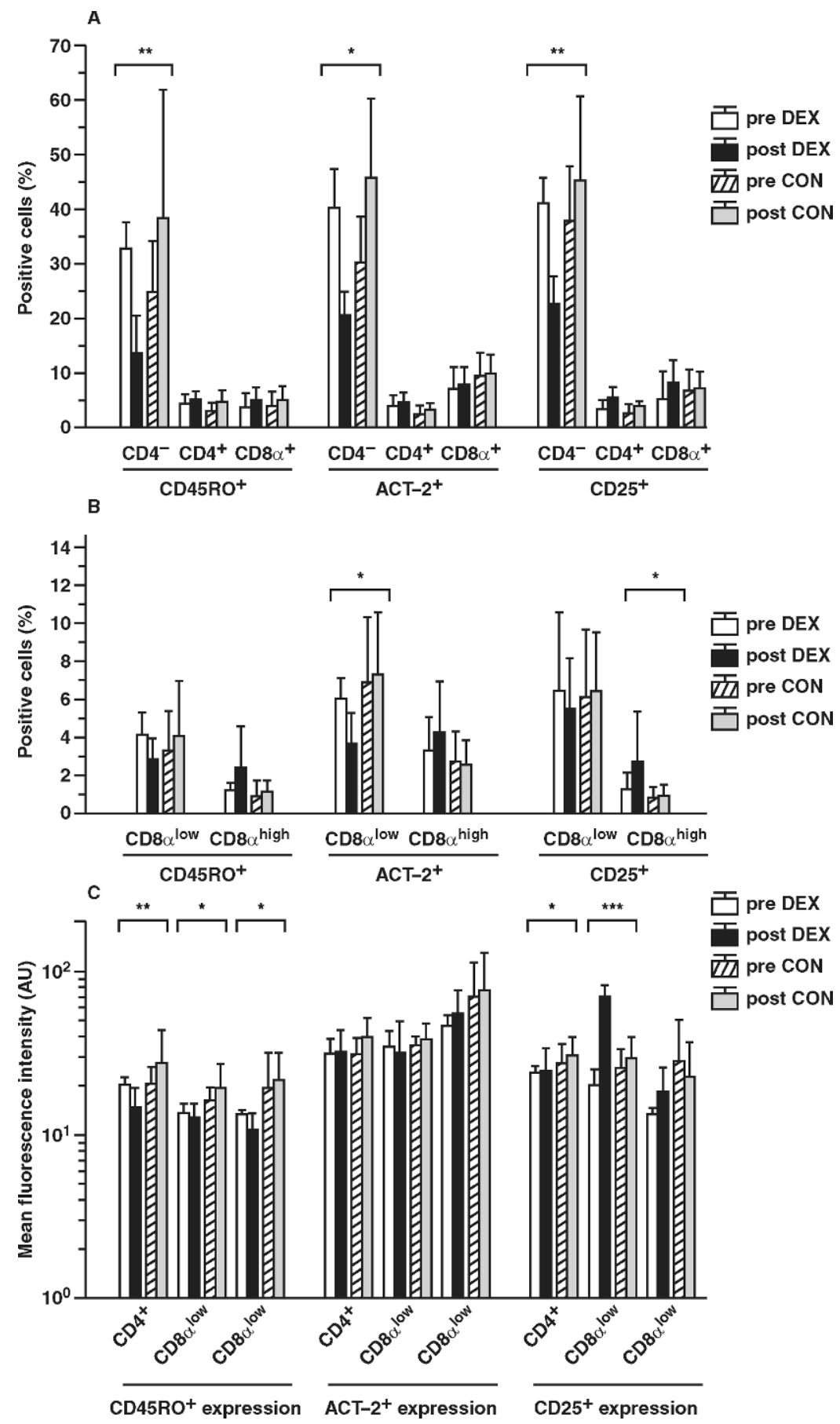

Figure 3. Influence of dexamethasone (DEX) treatment in vivo on the activation state of circulating lymphocytes in calves. (A, B) Percentage of cells of the major peripheral lymphocyte subsets coexpressing memory cell and activation markers. (C) Average expression level of memory cell and activation markers by $\mathrm{CD} 4^{+}, \mathrm{CD} 8 \alpha^{\text {low }}$, and CD8 $\alpha^{\text {high }}$ subsets of peripheral lymphocytes. Mean fluorescence intensities for the detection of CD45RO, ACT-2, and CD25 are depicted as arbitrary units (AU). Cells were analyzed as in Figure 1. Values represent mean \pm SD of determinations from all animals per group/sampling time [each blood sample examined in duplicate; treatment group $(\mathrm{n}=4$ to 6 calves): sampling before DEX treatment (pre DEX), sampling $48 \mathrm{~h}$ after the onset of DEX treatment (post DEX); nontreated group ( $\mathrm{n}=$ 6 calves): first sampling (pre CON) and second sampling $48 \mathrm{~h}$ later (post CON)]. Significances for the combined impact of group and sampling time $\left(P_{\text {group/time }}\right)$ on a given parameter are indicated by asterisks: $* P \leq 0.05 ; * * P \leq 0.01 ; * * * \leq 0.001$. 


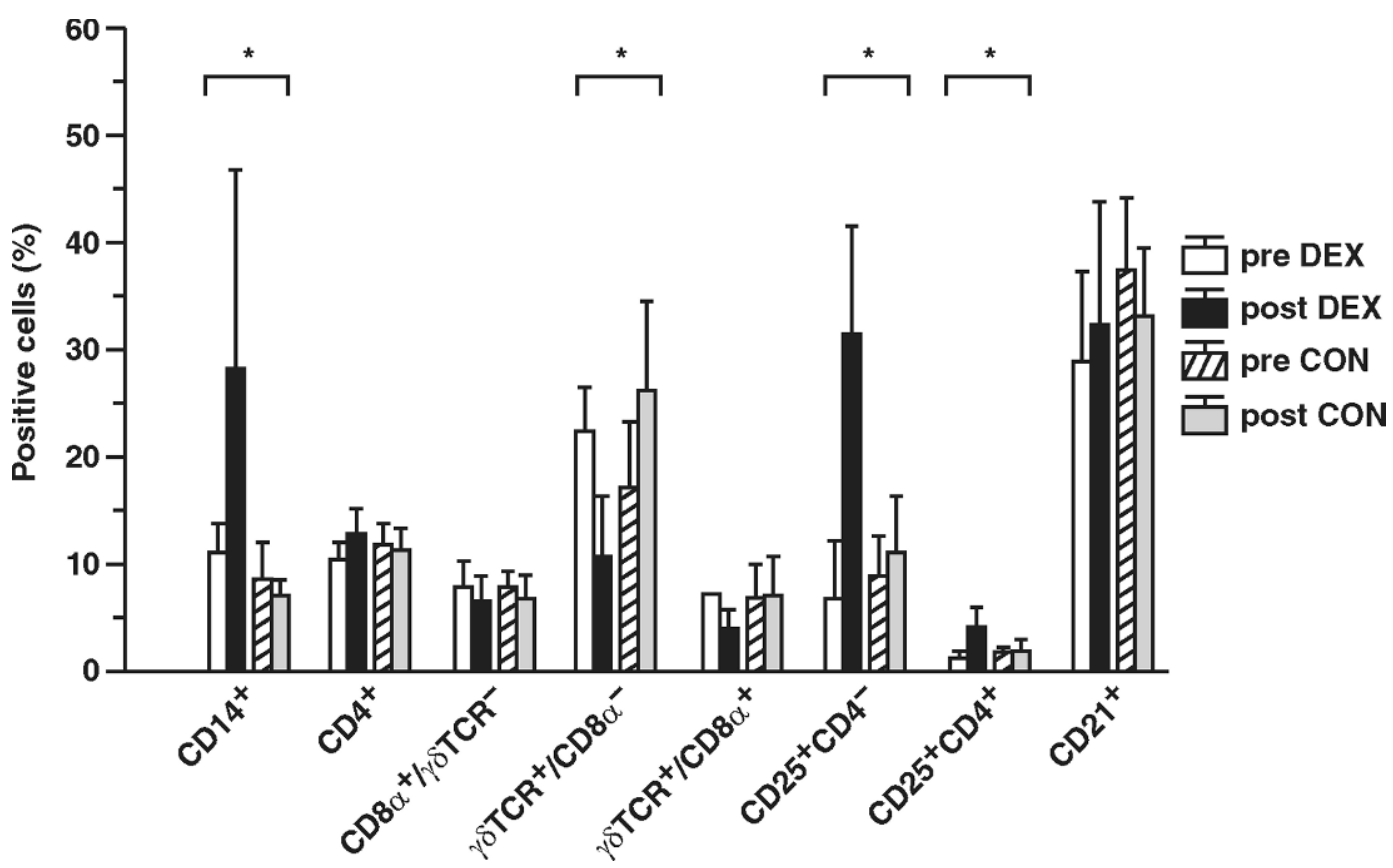

Figure 4. Influence of dexamethasone (DEX) treatment on the composition of peripheral blood mononuclear cells (PBMC) in calves. Cells were separated from peripheral blood by Ficoll gradient, labeled, and analyzed. Percentages of all cells in the preparation staining positive or negative, respectively, with the indicated markers are depicted. Values represent mean \pm SD of determinations from all animals per group/sampling time [each PBMC preparation examined in duplicate; treatment group ( $\mathrm{n}=2$ to 4 calves): sampling before DEX treatment (pre DEX), sampling $48 \mathrm{~h}$ after the onset of DEX treatment (post DEX); nontreated group ( $\mathrm{n}=4$ calves): first sampling (pre CON) and second sampling $48 \mathrm{~h}$ later (post CON)]. Significances for the combined impact of group and sampling time $\left(P_{\text {group/time }}\right)$ on a given parameter are indicated by asterisks: $* P \leq 0.05$.

\section{DISCUSSION}

The results of this study demonstrated that treatment with DEX had complex effects on bovine peripheral blood lymphocytes and that different peripheral blood lymphocyte subpopulations responded differently to DEX. Detailed analyses of the phenotype and responsiveness of peripheral blood lymphocytes after DEX treatment of calves confirmed earlier reports that DEX particularly reduces the number of circulating $\gamma \delta \mathrm{T}$ cells, a subset that is more abundant in the peripheral blood of ruminants than in any other species. We also identified additional distinct effects of DEX (e.g., increase in CD25+ expression on CD8 $\alpha^{\text {low }} \mathrm{T}$ cells, increase in the proliferative capacity and activatability of $\mathrm{CD} 4^{+} \mathrm{T}$ cells, alterations of cytokine transcription patterns). These findings are similar to those in other species and support our hypothesis that DEX exerts a complex action in the bovine adaptive immune response.

\section{DEX Treatment as a Model of Stress-Induced Impairment of the Bovine Immune System}

It is well established that the suppressive effect of DEX on bovine T-lymphocyte function is dependent on dosage and pharmacokinetics of the drug, physiological adaptation of the animal, dose of mitogen used to restimulate the cells in vitro, and time of cellular evaluation after drug treatment (Pruett et al., 1987; Oldham and Howard, 1992). We selected a high-dose DEX application $(0.25 \mathrm{mg} / \mathrm{kg}$ per $\mathrm{d}$ for $2 \mathrm{~d}$, administered i.v.) for this initial study to identify DEX-induced alterations in peripheral bovine lymphocyte subsets. This high dose was based on the experimental design used to intensify the interaction of shigatoxigenic $E$. coli $\mathrm{O} 157: \mathrm{H} 7$ with the mucosal surfaces of calves (Stoffregen et al., 2004). It remains to be determined to what extent the DEX model is relevant to natural, acute stress-induced effects. In addition, it should be established whether lower concentrations of plasma GC following administration of exogenous GC or endogenous increases associated with (patho)physiological conditions such as stress and parturition also result in detectable changes in the parameters investigated herein. Notably, calves allowed free-range grazing and access to their mothers have a significantly greater proportion of $\gamma \delta \mathrm{T}$ cells in their blood compared with age- and breed-matched calves held in conventional housing (Baldwin et al., 2000). In dairy cows, all T-cell subset populations, including $\gamma \delta$ T cells (Van Kampen and Mallard, 1997; Kimura et al., 2002) decrease at the time of parturition, 


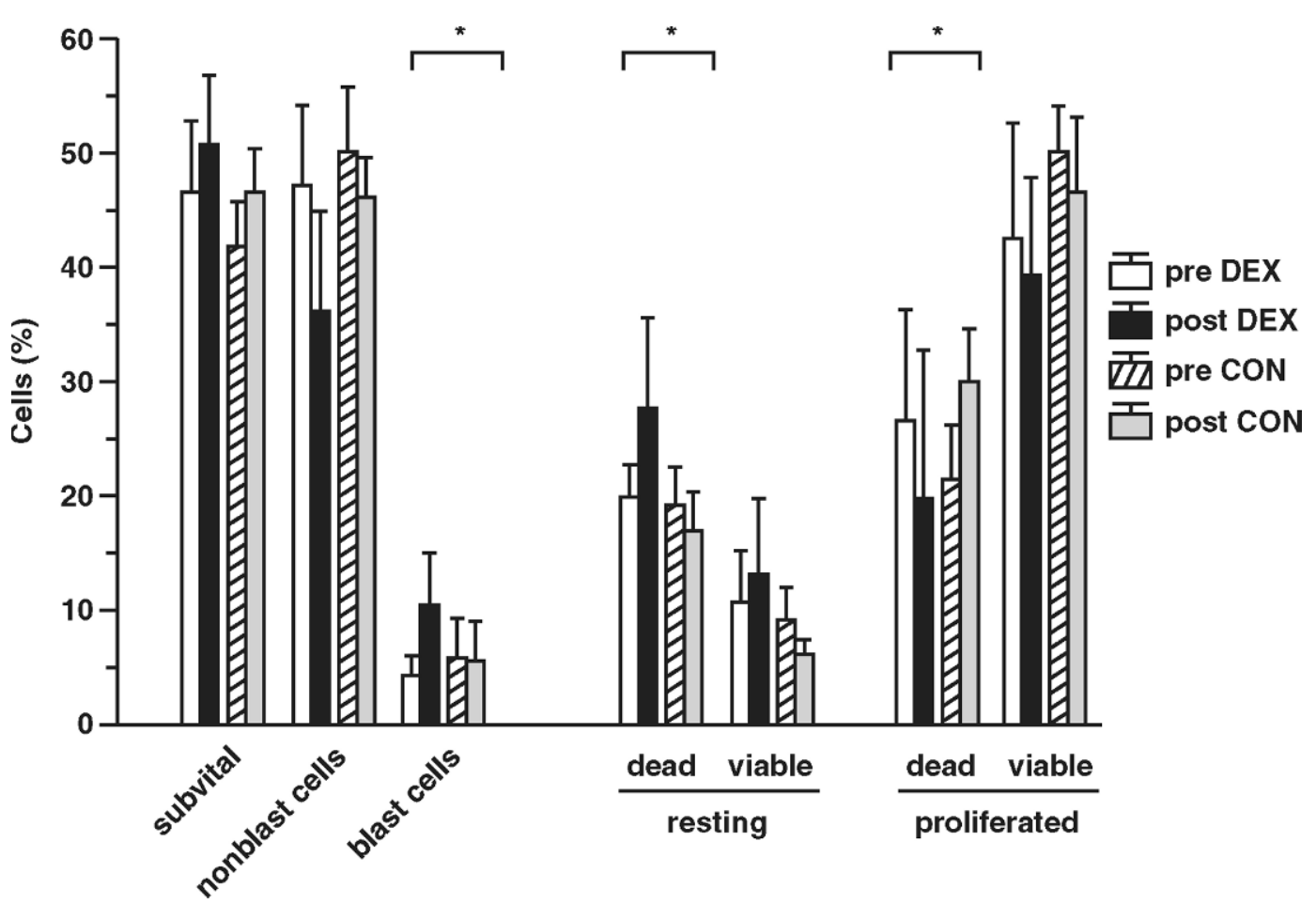

Figure 5. Influence of dexamethasone (DEX) treatment on the morphology and proliferative capacity of peripheral blood mononuclear cells (PBMC). PKH67-labeled PBMC were cultured with phytohemagglutinin-P $(5 \mu \mathrm{g} / \mathrm{mL})$ for $96 \mathrm{~h}$ and subsequently analyzed by flow cytometry. The numbers of cells with light-scattering characteristics of subvital cells, nonblast cells, and blast cells were determined. In parallel, the numbers of cells with unchanged (resting) and reduced (proliferated) PKH67 signal, with (dead) and without altered membrane integrity (viable) were recorded. Percentages of all cells in the PBMC culture displaying the respective characteristics are depicted. Values represent mean $\pm \mathrm{SD}$ of determinations from all animals per group/preparation time [each PBMC culture examined 16-fold; treatment group ( $\mathrm{n}=6$ calves): sampling before DEX treatment (pre DEX), sampling $48 \mathrm{~h}$ after the onset of DEX treatment (post DEX); nontreated group ( $\mathrm{n}=4$ calves): first sampling (pre CON) and second sampling $48 \mathrm{~h}$ later (post CON)]. Significances for the combined impact of group and sampling time $\left(P_{\text {group/time }}\right)$ on a given parameter are indicated by asterisks: $* P \leq 0.05$.

whereas the percentage of monocytes increases (Kimura et al., 2002). Peripartum stress also was associated with alterations of circulating lymphocyte functions, namely, a Th2-bias of the Th1/Th2 balance (Shafer-Weaver and Sordillo, 1997; Shafer-Weaver et al., 1999) and a reduced cytotoxic activity of $\mathrm{CD}^{+} \mathrm{T}$ cells (Shafer-Weaver and Sordillo, 1997). Thus, it may be possible to use delayed-response indicators of elevated GC levels (e.g., the percentage of $\gamma \delta \mathrm{T}$ cells) to quantify the impact of repeated or chronic stress on animal welfare.

\section{Effects of DEX Treatment on the Composition of Circulating Lymphocytes}

Several lines of evidence indicate that DEX treatment differentially depletes distinct lymphocyte subsets from bovine blood, but findings regarding the subpopulations affected are inconsistent. Several investigators noted a rapid decline in the percentage of $\gamma \delta \mathrm{T}$ cells and a concomitant decline in the percentage of $\mathrm{B}$ cells following DEX administration (Oldham and How- ard, 1992; Burton and Kehrli, 1996; Nonnecke et al., 1997; Saama et al., 2004). However, in another study, the percentage of $\gamma \delta \mathrm{T}$ cells declined without a decline in the percentage of B cells (Moire et al., 2002). These discrepant results may be explained by the fact that all of these studies characterized mononuclear cells (PBMC) separated from whole blood by means of density gradients. A variable loss of cells belonging to a certain subset during gradient performance may have adversely affected the values obtained. In support of Moire et al. (2002), we did not observe an effect of DEX on the percentage of B cells within PBMC from DEXtreated calves. When we analyzed circulating leukocytes, however, we noticed a significant increase in the percentage of $\mathrm{CD} 21^{+} / \mathrm{CD}^{-} \mathrm{B}$ cells, confirming findings by Anderson et al. (1999).

Previous studies, which did not take into account the overlapping expression of CD8 $\alpha$ on $\alpha \beta \mathrm{T}$ cells and $\gamma \delta \mathrm{T}$ cells, concluded that DEX treatment does not influence the percentage of $\mathrm{CD}^{+} \mathrm{T}$ cells in PBMC (Oldham and Howard, 1992; Burton and Kehrli, 1996; Moire et al., 2002) but decreases the percentage of circulating $\mathrm{CD} 8^{+}$ 


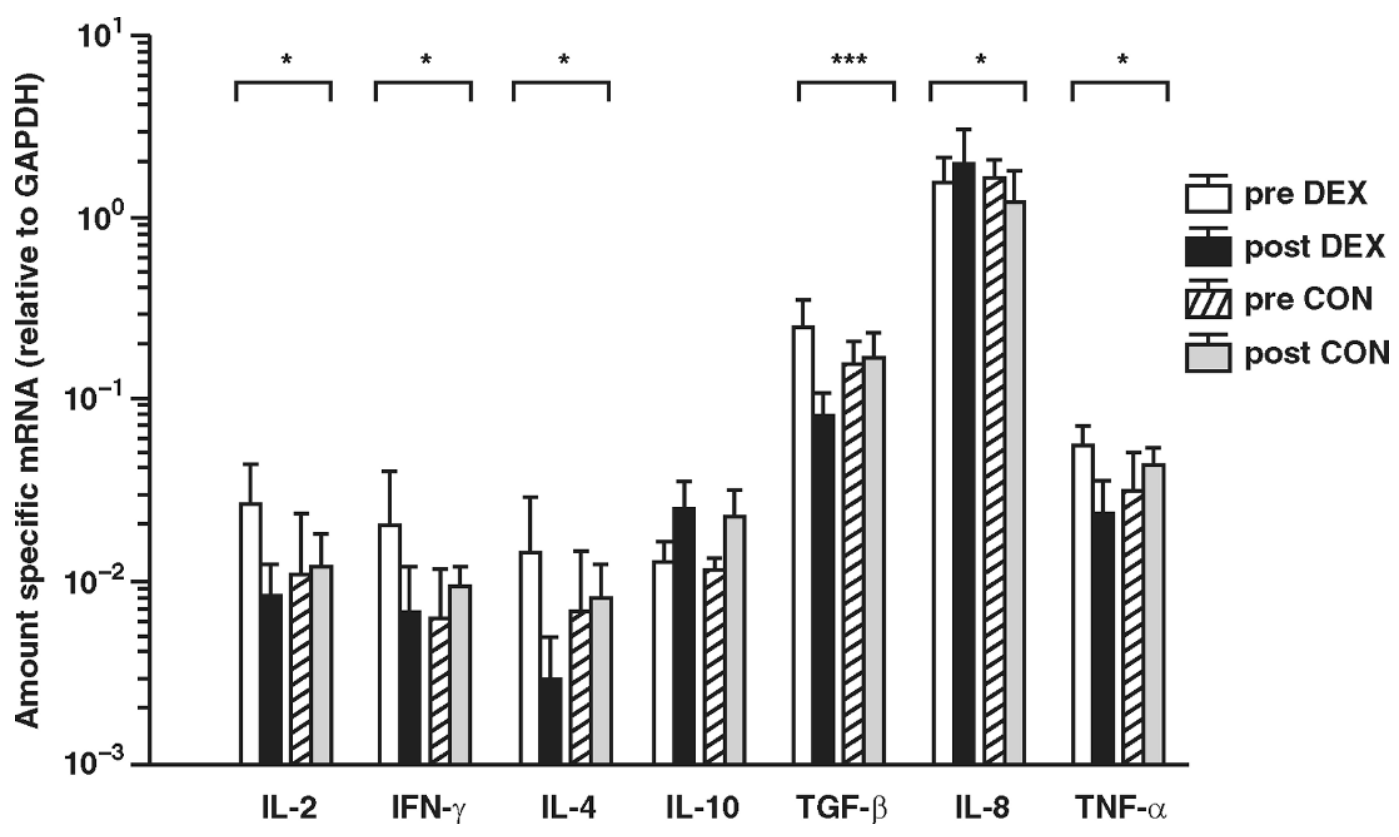

Figure 6. Relative amounts of gene transcripts [n-fold the amount of GAPDH transcripts (set to 1 -fold $=10^{\circ}$ ) in the same sample] harbored by PBMC from calves with and without dexamethasone (DEX) treatment after short-term culture (7.5 h) with phytohemagglutinin$\mathrm{P}(5 \mu \mathrm{g} / \mathrm{mL})$. Values represent mean $\pm \mathrm{SD}$ of determinations from all animals per group/sampling time [each PBMC preparation examined in duplicate; treatment group ( $\mathrm{n}=5$ calves): sampling before DEX treatment (pre DEX), sampling $48 \mathrm{~h}$ after the onset of DEX treatment (post DEX); nontreated group ( $\mathrm{n}=4$ calves): first sampling (pre CON) and second sampling $48 \mathrm{~h}$ later (post CON)]. Significances for the combined impact of group and sampling time $\left(P_{\text {group/time }}\right)$ on a given parameter are indicated with asterisks: $* P \leq 0.05$; **** $P \leq 0.001$. Twoway ANOVA further revealed a significant impact of the sampling time independent of the animal group on the amounts of IL-10- and transforming growth factor- $\beta$-specific mRNA ( $P_{\text {time }} \leq 0.01$ and $P_{\text {time }} \leq 0.001$, respectively).

T cells (Anderson et al., 1999). When we separately analyzed CD $8 \alpha^{\text {high }} \alpha \beta \mathrm{T}$ cells and $\mathrm{CD} 8 \alpha^{\text {low }} \gamma \delta \mathrm{T}$ cells, we discovered that DEX treatment reduced the latter subpopulation within both circulating lymphocytes and isolated PBMC. Further distinctions among $\mathrm{CD} 8 \alpha^{-}$, $\mathrm{CD} 8 \alpha^{\text {low }}$, and $\mathrm{CD} 8 \alpha^{\text {high }}$ subsets of circulating $\gamma \delta \mathrm{T}$ cells provided preliminary evidence that DEX treatment depleted the $\mathrm{CD} 8 \alpha^{-}$subset more profoundly than it did the CD8 $\alpha^{\text {low }}$ subset, whereas the CD8 $\alpha^{\text {high }}$ subset of $\gamma \delta \mathrm{T}$ cells was not affected (data not shown). Because, beyond CD8 $\alpha$ expression (Tuo et al., 1999), $\gamma \delta$ T cells in cattle can be subdivided into a number of different subsets with distinct functions (Rogers et al., 2005), future studies should place special emphasis on phenotypical and functional analyses of the effects of DEX on various $\gamma \delta$ T-cell subsets.

\section{Effects of DEX Treatment on the Activation and Memory Cell Marker Expression by Circulating Lymphocytes}

Analyses of circulating lymphocytes and of Ficollseparated PBMC in the present study yielded conflicting results regarding the effects of DEX on activation marker expression. The percentage of circulating $\mathrm{CD}_{4}^{-} /$
$\mathrm{CD} 25^{+}$cells in DEX-treated calves was reduced by half. In contrast, the numbers of $\mathrm{CD} 4^{-} / \mathrm{CD}^{2} 5^{+} \mathrm{T}$ cells were significantly elevated in PBMC from DEX-treated calves. Considering earlier findings of a significantly elevated number of circulating CD25+ lymphocytes in DEX-treated cattle (Anderson et al., 1999), our findings strengthen the notion that DEX administration alters the activation state of bovine peripheral lymphocytes. Nonnecke et al. (1997) observed an increased number of MHC-II-expressing cells and a reduced MHC-II expression per single cell in Percoll-enriched PBMC from DEX-treated bulls. On the basis of their observation that the number of $\mathrm{B}$ cells was reduced and the fact that bovine T cells express MHC-II on activation (Quade and Roth, 1999), the observed changes in MHC-II expression pattern may be interpreted as an altered activation state of peripheral T cells in DEX-treated cattle.

Dexamethasone-induced changes in activation marker expression have not yet been assigned to lymphocyte subsets. Dual-color flow cytometry, which is particularly useful for separately defining alterations in the activation state of different lymphocyte subsets (Quade and Roth, 1999), allowed us to expose remarkable differences among the subsets. Although the percentage of $\mathrm{CD}^{-}$cells expressing CD25 was significantly 
decreased, the percentage of $\mathrm{CD} 4^{+}$cells and $\mathrm{CD} 8 \alpha^{+}$cells coexpressing this marker was slightly, although not significantly, increased. Separate analyses of CD8 $\alpha^{\text {low }}$ and $\mathrm{CD} 8 \alpha^{\text {high }}$ lymphocytes clearly showed that an increased portion of activated (i.e., $\mathrm{CD} 25^{+}$) cells was confined to the $\mathrm{CD} 8 \alpha^{\text {high }}$ subset. The $\mathrm{CD} 8 \alpha^{\text {low }}$ population (i.e., a $\gamma \delta \mathrm{T}$-cell subset), on the contrary, was characterized by an increased number of CD25 molecules per cell, indicating an elevated activation state on the single-cell level. This finding is consistent with data suggesting that, during an acute stress response, endogenous stress hormones such as GC help prepare the host for infections by enhancing skin immunity by increasing leukocyte trafficking and cytokine gene expression at sites of potential antigen entry (Dhabhar and McEwen, 1997; Dhabhar et al., 2000).

Percentages of $\mathrm{CD}^{+}$and $\mathrm{CD} 8^{+}$cells coexpressing CD45RO were unaltered by DEX treatment, but DEX dramatically reduced the proportion of $\mathrm{CD}^{-} / \mathrm{CD} 45 \mathrm{RO}^{+}$ cells. Dexamethasone treatment also reduced the average surface expression of CD45RO on $\mathrm{CD}^{+}$and CD8 $\alpha^{\text {high }}$ lymphocytes. Because bovine B cells do not express CD45RO (Bembridge et al., 1995), we hypothesize that the reduction in $\mathrm{CD}^{2} 5 \mathrm{RO}^{+}$cells occurred within the $\gamma \delta \mathrm{T}$ cells. The reduced CD45RO expression may be indicative of varying effects of DEX on different lymphocyte subsets. Antigenically primed bovine $\mathrm{CD} 4^{+}$ $\mathrm{T}$ cells remain $\mathrm{CD}^{2} 5 \mathrm{RO}^{+}$, and expression of this molecule consequently identifies memory cells, but antigenically primed $\mathrm{CD}^{+} \mathrm{T}$ cells down-regulate $\mathrm{CD} 45 \mathrm{RO}$ expression after activation (Bembridge et al., 1995). The results of our study provide evidence that DEX treatment of calves alters the activation state of distinct lymphocyte subpopulations in different ways. The observed changes in activation marker expression now await confirmation by functional analyses particularly emphasizing the $\gamma \delta \mathrm{T}$-cell subsets.

\section{Effect of DEX Treatment on the Proliferative Capacity of PBMC}

Our observation that treatment of cattle with DEX suppressed the proliferative capacity of lymphocytes in vitro is consistent with earlier reports that DEX treatment of cattle resulted in decreased cell proliferation in lymphoid follicles in vivo (Norrman et al., 2003) and in vitro (Oldham and Howard, 1992). It has been suggested that GC normally contribute to steady-state regulation of lymphopoiesis in humans because the earliest events in human lymphopoiesis are particularly susceptible to injury during GC therapy (Igarashi et al., 2005). Dexamethasone also accelerates apoptosis in nonactivated human lymphocytes (Totino et al., 2006). Shortterm, high-dose immunosuppressive therapy with GC was proposed to destroy GC-sensitive lymphocytes in calves (Muscoplat et al., 1975). Indeed, decreased cell proliferation rates in follicles of Peyer's patches and thymus in DEX-treated neonatal calves are accompanied by an increased apoptotic rate (Norrman et al., 2003). In line with the assumption that the decrease in circulating lymphocyte numbers in DEX-treated calves results from an increased susceptibility of progenitor cells to undergo apoptosis, a reduced proliferative capacity of PBMC in our study coincided with a significant increase in cells that died before cell division in vitro. Apoptosis probably also explains the shift within the lymphocyte population because different subsets may not be equally sensitive to DEX-accelerated apoptosis. Murine $\mathrm{CD}^{+} / \mathrm{CD} 25^{+} \mathrm{T}$ cells, for example, express higher levels of Bcl-2 and are more resistant to DEXmediated cell death than are $\mathrm{CD} 4^{+} / \mathrm{CD} 25^{-} \mathrm{T}$ cells (Chen et al., 2004).

\section{Implications of $\mathrm{CD} 4^{+} / \mathrm{CD} 25^{+} \mathrm{T}$ Cells on the Proliferative Capacity of PBMC}

Although in our study the overall proliferative capacity of PBMC was reduced, analysis of proliferating subpopulations revealed a markedly increased percentage of $\mathrm{CD}^{+}$cells. This implies that at least a subpopulation of bovine $\mathrm{CD} 4^{+}$lymphocytes resisted the DEX effect. A similar observation was made by Oldham and Howard (1992). Because DEX-treated CD $4^{+} / \mathrm{CD} 25^{+} \mathrm{T}$ cells inhibit proliferation of $\mathrm{CD}^{+} / \mathrm{CD} 25^{-} \mathrm{T}$ cells, it was assumed that DEX treatment may be permissive for the survival of functional CD $4^{+} / \mathrm{CD} 25^{\text {high }} \mathrm{T}$ regulatory cells ( $\mathbf{T}_{\text {reg }}$, and this property may contribute to the antiinflammatory and immunosuppressive efficacy of GC (Chen et al., 2004). We observed an increase in $\mathrm{CD}^{+} /$ $\mathrm{CD} 25^{+}$cells within circulating lymphocytes and PBMC, although the effect was significant in the latter case only. The low number of $\mathrm{CD} 4^{+} / \mathrm{CD} 25^{+}$cells led us to refrain from separately analyzing $\mathrm{CD} 4^{+} / \mathrm{CD} 25^{\text {low }}$ and $\mathrm{CD} 4^{+} / \mathrm{CD} 25^{\text {high }}$ cells. It is tempting to hypothesize that an increase in $\mathrm{CD} 4^{+} / \mathrm{CD} 25^{+} \mathrm{T}_{\text {reg }}$ contributed to the changes in lymphocyte composition in vivo and the reduced proliferative response of PBMC in vitro. On the contrary, it also must be considered that DEX not only prolongs $\mathrm{T}_{\text {reg }}$ survival, but also induces in vitro the de novo expression of CD25 by human $\mathrm{CD}^{+} \mathrm{T}$ cells that initially were CD25- (i.e., cells that likely do not represent natural $\mathrm{T}_{\text {reg }}$; Chung et al., 2004). The increased number of $\mathrm{CD} 4^{+} / \mathrm{CD} 25^{+} \mathrm{PBMC}$ in the present study may result from an early induction of CD25 on DEXsensitized $\mathrm{CD} 4^{+}$cells during the separation procedure, rather than reflecting an increase in the number of $\mathrm{T}_{\text {reg. }}$. In fact, the increased number of $\mathrm{CD} 4^{+} / \mathrm{CD} 25^{+} \mathrm{PBMC}$ was not accompanied by an increase in mRNA for TGF- 
$\beta$, a major effector cytokine of $\mathrm{T}_{\text {reg }}$ in humans and mice. Moreover, TGF- $\beta$-mRNA was even found to be reduced in PBMC from DEX-treated calves in this study.

\section{Implications of Cytokines on the Proliferative Capacity of PBMC}

Despite the yet-to-be-defined role of $\mathrm{T}_{\text {reg }}$, further evidence exists that the suppressive effects of DEX in cattle in part originate indirectly from an altered ability of subset(s) of cells to produce and secrete mediators of the immune system. Although administration of IL2 does not overcome the influence of DEX on bovine lymphocyte responsiveness in DEX-treated cattle (Roth et al., 1990), IL-2 activity is reduced in GC-treated bovine PBMC cultures (Blecha and Baker, 1986) and addition of exogenous IL-2 restores phytohemagglutinin responsiveness of bovine lymphocytes in the presence of DEX in vitro (Oldham and Howard, 1992). Interferon$\gamma$ treatment prevents the DEX-induced exacerbation of pneumonia following Histophilus somni infection in calves (Chiang et al., 1990), implying that the effect of DEX in this model, at least in part, results from a reduction in IFN- $\gamma$ production. Indeed, in vivo administration of DEX almost completely blocks in vitro secretion of IFN- $\gamma$ by mitogen-stimulated PBMC (Nonnecke et al., 1997). The reduced amounts of cytokine-specific mRNA in PBMC from DEX-treated calves discovered in our study strongly indicate that DEX suppresses cytokine secretion in cattle by acting at the transcriptional level.

Interferon- $\gamma$ protein secretion in vitro was shown to be positively associated with the proportion of $\mathrm{CD}^{+} \mathrm{T}$ cells (primarily $\gamma \delta \mathrm{T}$ cells) within the PBMC from DEXtreated bulls (Nonnecke et al., 1997) and at parturition in cows (Nonnecke et al., 2003). It may be argued that the reduction in IFN- $\gamma$-mRNA reported here is attributable to the decrease in the portion of $\gamma \delta \mathrm{T}$ cells in the cultures. However, we also noted a comparable decrease in IL-4-specific mRNA. The latter cannot be explained by reduced $\gamma \delta$ T-cell numbers because the vast majority of peripheral blood $\gamma \delta \mathrm{T}$ cells in cattle are IL-4 negative (Baldwin et al., 2000) and $\mathrm{CD}^{+}{ }^{+} \mathrm{T}$ cells are the main IFN- $\gamma$ source in bovine lymphocyte cultures (Baldwin et al., 2002). We therefore interpret the reduced amounts of several mRNA species as evidence for a substantial suppression of gene transcription in lymphocytes from DEX-treated calves on a single-cell level.

Contradictory results have been published concerning the effect of GC on cytokine production in human lymphocytes. Some investigators claimed that GC treatment results in IL-4 enhancement and IFN- $\gamma$ inhibition (Snijdewint et al., 1995; Agarwal and Marshall, 2001), whereas others stated that IL-4 and IFN- $\gamma$ are equally down-regulated (Braun et al., 1997). The ratios between IL-4-specific and IFN- $\gamma$-specific mRNA detected in the present study remained just below 1 throughout, whether the mRNA had been quantified in cultures of PBMC from DEX-treated or nontreated calves (data not shown). Notably, DEX treatment did not affect the amount of IL-10-specific mRNA. This mRNA species may have originated from Th2-biased lymphocytes or $\mathrm{T}_{\text {reg }}$ as well as from monocytes. The latter cell type was significantly increased in number in PBMC derived from DEX-treated calves. An upregulation of IL-10 production by monocytes, as reported for human cells (Mozo et al., 2004; Xia et al., 2005), might have masked a reduction in il-10 transcription in lymphocytes. Further studies are required for a comprehensive understanding of whether DEX treatment dysregulates the Th1/Th2 cytokine profile in cattle, as has been proposed for mice (Viveros-Paredes et al., 2006) and as can be observed in dairy cows during the postpartum period (Shafer-Weaver and Sordillo, 1997; Shafer-Weaver et al., 1999).

Our results led us to suggest that, similar to other species, DEX does not generally down-regulate the adaptive immune response in cattle but has various effects on different elements of the immune response. Analysis of unseparated leukocytes identified distinct effects of DEX treatment on the number of lymphocytes belonging to different subsets and on the activation state of the respective subsets. Further functional studies are needed to dissect the effects this GC exerts on different immune cells (i.e., lymphocyte subsets) and on interactions among these subsets in the highly integrated immune system.

\section{ACKNOWLEDGMENTS}

We thank Bryan K. Wheeler, Amanda M. Scherer, Nate Horman, and Bruce Pesch at USDA, Agricultural Research Service, NADC, for excellent technical assistance. Klaus Failing, biomathematics workgroup, Justus-Liebig-University Giessen, is acknowledged for performing statistical analysis. William C. Stoffregen, Mitchell V. Palmer, David Alt, W. Ray Waters, and Marcus E. Kehrli Jr. at NADC are acknowledged for helpful discussions. We thank Anja Taubert, Institute for Parasitology, Justus-Liebig-University Giessen, for support with primers and probes for mRNA quantification. We are especially indebted to Joachim F. L. Pohlenz, Institute for Pathology, School of Veterinary Medicine, Hannover, Germany, for his outstanding support. This work was supported by the USDA Agricultural Research Service and the German Research Foundation (Bonn, Germany). 


\section{REFERENCES}

Abraham, G., J. Gottschalk, and F. R. Ungemach. 2004. Possible role of dexamethasone in sensitizing the beta-2-adrenergic receptor system in vivo in calves during concomitant treatment with clenbuterol. Pharmacology 72:196-204.

Agarwal, S. K., and G. D. Marshall Jr. 2001. Dexamethasone promotes type 2 cytokine production primarily through inhibition of type 1 cytokines. J. Interferon Cytokine Res. 21:147-155.

Anderson, B. H., D. L. Watson, and I. G. Colditz. 1999. The effect of dexamethasone on some immunological parameters in cattle. Vet. Res. Commun. 23:399-413.

Baldwin, C. L., T. Sathiyaseelan, B. Naiman, A. M. White, R. Brown, S. Blumerman, A. Rogers, and S. J. Black. 2002. Activation of bovine peripheral blood $\gamma \delta$ T cells for cell division and IFN- $\gamma$ production. Vet. Immunol. Immunopathol. 87:251-259.

Baldwin, C. L., T. Sathiyaseelan, M. Rocchi, and D. McKeever. 2000. Rapid changes occur in the percentage of circulating bovine $\mathrm{WC}^{+}$ $\gamma \delta$ Th1 cells. Res. Vet. Sci. 69:175-180.

Barnes, P. J. 2006. Corticosteroids: The drugs to beat. Eur. J. Pharmacol. 533:2-14.

Belvisi, M. G. 2004. Regulation of inflammatory cell function by corticosteroids. Proc. Am. Thorac. Soc. 1:207-214.

Bembridge, G. P., N. D. MacHugh, D. McKeever, E. Awino, P. Sopp, R. A. Collins, K. I. Gelder, and C. J. Howard. 1995. CD45RO expression on bovine T cells: Relation to biological function. Immunology 86:537-544.

Blecha, F., and P. E. Baker. 1986. Effect of cortisol in vitro and in vivo on production of bovine interleukin 2 . Am. J. Vet. Res. 47:841-845.

Braun, C. M., S. K. Huang, G. G. Bashian, A. Kagey-Sobotka, L. M. Lichtenstein, and D. M. Essayan. 1997. Corticosteroid modulation of human, antigen-specific Th1 and Th2 responses. J. Allergy Clin. Immunol. 100:400-407.

Burton, J. L., and M. E. Kehrli Jr. 1995. Regulation of neutrophil adhesion molecules and shedding of Staphylococcus aureus in milk of cortisol- and dexamethasone-treated cows. Am. J. Vet. Res. 56:997-1006.

Burton, J. L., and M. E. Kehrli Jr. 1996. Effects of dexamethasone on bovine circulating $\mathrm{T}$ lymphocyte populations. J. Leukoc. Biol. 59:90-99.

Burton, J. L., M. E. Kehrli Jr., S. Kapil, and R. L. Horst. 1995. Regulation of L-selectin and CD18 on bovine neutrophils by glucocorticoids: Effects of cortisol and dexamethasone. J. Leukoc. Biol. 57:317-325.

Chen, X., T. Murakami, J. J. Oppenheim, and O. M. Howard. 2004. Differential response of murine $\mathrm{CD} 4^{+} \mathrm{CD} 25^{+}$and $\mathrm{CD} 4^{+} \mathrm{CD} 25^{-} \mathrm{T}$ cells to dexamethasone-induced cell death. Eur. J. Immunol. 34:859-869.

Chiang, Y. W., J. A. Roth, and J. J. Andrews. 1990. Influence of recombinant bovine interferon gamma and dexamethasone on pneumonia attributable to Haemophilus somnus in calves. Am. J. Vet. Res. 51:759-762.

Chung, I. Y., H. F. Dong, X. Zhang, N. M. Hassanein, O. M. Howard, J. J. Oppenheim, and X. Chen. 2004. Effects of IL-7 and dexamethasone: Induction of CD25, the high affinity IL-2 receptor, on human $\mathrm{CD}^{+}$cells. Cell. Immunol. 232:57-63.

Dhabhar, F. S., and B. S. McEwen. 1997. Acute stress enhances while chronic stress suppresses cell-mediated immunity in vivo: A potential role for leukocyte trafficking. Brain Behav. Immun. 11:286-306.

Dhabhar, F. S., A. R. Satoskar, H. Bluethmann, J. R. David, and B. S. McEwen. 2000. Stress-induced enhancement of skin immune function: A role for gamma interferon. Proc. Natl. Acad. Sci. USA 97:2846-2851.

Dixon, W., ed. 1993. BMDP Statistical Software Manual. Vol. 1 and 2. Univ. California, Los Angeles, CA.

Estrada, A., A. van Kessel, and B. Laarveld. 1999. Effect of administration of oat beta-glucan on immune parameters of healthy and immunosuppressed beef steers. Can. J. Vet. Res. 63:261-268.
Georas, S. N. 2004. Inhaled glucocorticoids, lymphocytes, and dendritic cells in asthma and obstructive lung diseases. Proc. Am. Thorac. Soc. 1:215-221.

Igarashi, H., K. L. Medina, T. Yokota, M. I. Rossi, N. Sakaguchi, P. C. Comp, and P. W. Kincade. 2005. Early lymphoid progenitors in mouse and man are highly sensitive to glucocorticoids. Int. Immunol. 17:501-511.

Kimura, K., J. P. Goff, M. E. Kehrli Jr., J. A. Harp, and B. J. Nonnecke. 2002. Effects of mastectomy on composition of peripheral blood mononuclear cell populations in periparturient dairy cows. J. Dairy Sci. 85:1437-1444.

Leutenegger, C. M., A. M. Alluwaimi, W. L. Smith, L. Perani, and J. S. Cullor. 2000. Quantitation of bovine cytokine mRNA in milk cells of healthy cattle by real-time TaqMan polymerase chain reaction. Vet. Immunol. Immunopathol. 77:275-287.

Lippolis, J. D., B. D. Peterson-Burch, and T. A. Reinhardt. 2006. Differential expression analysis of proteins from neutrophils in the periparturient period and neutrophils from dexamethasonetreated dairy cows. Vet. Immunol. Immunopathol. 111:149-164.

Lomborg, S. R., J. S. Agerholm, A. L. Jensen, and L. R. Nielsen. 2007. Effects of experimental immunosuppression in cattle with persistently high antibody levels to Salmonella Dublin lipopolysaccharide O-antigens. BMC Vet. Res. 3:17.

Mansell, P. D., A. R. Cameron, D. P. Taylor, and J. Malmo. 2006. Induction of parturition in dairy cattle and its effects on health and subsequent lactation and reproductive performance. Aust. Vet. J. 84:312-316.

Menge, C., J. Stamm, M. Wuhrer, R. Geyer, L. H. Wieler, and G. Baljer. 2001. Globotriaosylceramide $\left(\mathrm{Gb}_{3} / \mathrm{CD} 77\right)$ is synthesized and surface expressed by bovine lymphocytes upon activation in vitro. Vet. Immunol. Immunopathol. 83:19-36.

Moire, N., O. Roy, and L. Gardey. 2002. Effects of dexamethasone on distribution and function of peripheral mononuclear blood cells in pneumonic calves. Vet. Immunol. Immunopathol. 87:459-466.

Moussay, E., I. Stamm, A. Taubert, G. Baljer, and C. Menge. 2006. Escherichia coli Shiga toxin 1 enhances IL-4 transcripts in bovine ileal intraepithelial lymphocytes. Vet. Immunol. Immunopathol. 113:367-382.

Mozo, L., A. Suarez, and C. Gutierrez. 2004. Glucocorticoids up-regulate constitutive interleukin-10 production by human monocytes. Clin. Exp. Allergy 34:406-412.

Muscoplat, C. C., R. E. Shope Jr., A. W. Chen, and D. W. Johnson. 1975. Effects of corticosteroids on responses of bovine peripheral blood lymphocytes cultured with phytohemagglutinin. Am. J. Vet. Res. 36:1243-1244.

Nonnecke, B. J., J. L. Burton, and M. E. Kehrli Jr. 1997. Associations between function and composition of blood mononuclear leukocyte populations from Holstein bulls treated with dexamethasone. J. Dairy Sci. 80:2403-2410.

Nonnecke, B. J., K. Kimura, J. P. Goff, and M. E. Kehrli Jr. 2003. Effects of the mammary gland on functional capacities of blood mononuclear leukocyte populations from periparturient cows. J. Dairy Sci. 86:2359-2368.

Norrman, J., C. W. David, S. N. Sauter, H. M. Hammon, and J. W. Blum. 2003. Effects of dexamethasone on lymphoid tissue in the gut and thymus of neonatal calves fed with colostrum or milk replacer. J. Anim. Sci. 81:2322-2332.

Ohmann, H. B., P. E. Baker, and L. A. Babiuk. 1987. Effect of dexamethasone on bovine leukocyte functions and bovine herpesvirus type-1 replication. Can. J. Vet. Res. 51:350-357.

Oldham, G., and C. J. Howard. 1992. Suppression of bovine lymphocyte responses to mitogens following in vivo and in vitro treatment with dexamethasone. Vet. Immunol. Immunopathol. 30:161-177.

Pastoret, P. P., L. A. Babiuk, V. Misra, and P. Griebel. 1980. Reactivation of temperature-sensitive and non-temperature-sensitive infectious bovine rhinotracheitis vaccine virus with dexamethasone. Infect. Immun. 29:483-488.

Pruett, J. H., W. F. Fisher, and J. R. DeLoach. 1987. Effects of dexamethasone on selected parameters of the bovine immune system. Vet. Res. Commun. 11:305-323.

Quade, M. J., and J. A. Roth. 1999. Dual-color flow cytometric analysis of phenotype, activation marker expression, and proliferation of 
mitogen-stimulated bovine lymphocyte subsets. Vet. Immunol. Immunopathol. 67:33-45.

Rogers, A. N., D. G. Vanburen, E. E. Hedblom, M. E. Tilahun, J. C. Telfer, and C. L. Baldwin. 2005. $\gamma \delta \mathrm{T}$ cell function varies with the expressed WC1 coreceptor. J. Immunol. 174:3386-3393.

Roth, J. A., A. F. Abruzzini, and D. E. Frank. 1990. Influence of recombinant human interleukin-2 administration on lymphocyte and neutrophil function in clinically normal and dexamethasonetreated cattle. Am. J. Vet. Res. 51:546-549.

Roth, J. A., and M. L. Kaeberle. 1981. Effects of in vivo dexamethasone administration on in vitro bovine polymorphonuclear leukocyte function. Infect. Immun. 33:434-441.

Roth, J. A., and M. L. Kaeberle. 1985. Enhancement of lymphocyte blastogenesis and neutrophil function by avridine in dexamethasone-treated and nontreated cattle. Am. J. Vet. Res. 46:53-57.

Saama, P. M., J. B. Jacob, M. E. Kehrli Jr., A. E. Freeman, S. C. Kelm, A. L. Kuck, R. J. Tempelman, and J. L. Burton. 2004. Genetic variation in bovine mononuclear leukocyte responses to dexamethasone. J. Dairy Sci. 87:3928-3937.

Shafer-Weaver, K. A., C. M. Corl, and L. M. Sordillo. 1999. Shifts in bovine CD4+ subpopulations increase T-helper-2 compared with T-helper-1 effector cells during the postpartum period. J. Dairy Sci. 82:1696-1706.

Shafer-Weaver, K. A., and L. M. Sordillo. 1997. Bovine CD8 ${ }^{+}$suppressor lymphocytes alter immune responsiveness during the postpartum period. Vet. Immunol. Immunopathol. 56:53-64.

Sheskin, D. 2007. Handbook of Parametric and Nonparametric Statistical Procedures. 4th ed. Taylor and Francis Group, Boca Raton, FL.

Snijdewint, F. G., M. L. Kapsenberg, P. J. Wauben-Penris, and J. D. Bos. 1995. Corticosteroids class-dependently inhibit in vitro Th1and Th2-type cytokine production. Immunopharmacology 29:93-101.

Stoffregen, W. C., J. F. Pohlenz, and E. A. Dean-Nystrom. 2004 Escherichia coli $\mathrm{O} 157: \mathrm{H} 7$ in the gallbladders of experimentally infected calves. J. Vet. Diagn. Invest. 16:79-83.

Sustronck, B., P. Deprez, G. van Loon, J. Coghe, and E. Muylle. 1997. Efficacy of the combination sodium ceftiofur-flumethasone in the treatment of experimental Pasteurella haemolytica bronchopneumonia in calves. Zentralbl. Veterinarmed. A 44:179-187.
Thanasak, J., R. Jorritsma, A. Hoek, J. P. Noordhuizen, V. P. Rutten, and K. E. Muller. 2004. The effects of a single injection of dexamethasone-21-isonicotinate on the lymphocyte functions of dairy cows at two weeks post partum. Vet. Res. 35:103-112.

Totino, P. R., E. K. Riccio, S. Corte-Real, C. T. Daniel-Ribeiro, and M. de Fatima Ferreira-da-Cruz. 2006. Dexamethasone has proapoptotic effects on non-activated fresh peripheral blood mononuclear cells. Cell Biol. Int. 30:133-137.

Tuo, W., F. W. Bazer, W. C. Davis, D. Zhu, and W. C. Brown. 1999. Differential effects of type I IFNs on the growth of WC1 ${ }^{-} \mathrm{CD}^{+}$ $\gamma \delta \mathrm{T}$ cells and WC1+ CD8- $\gamma \delta \mathrm{T}$ cells in vitro. J. Immunol. 162:245-253.

Van Kampen, C., and B. A. Mallard. 1997. Effects of peripartum stress and health on circulating bovine lymphocyte subsets. Vet. Immunol. Immunopathol. 59:79-91.

Viveros-Paredes, J. M., A. M. Puebla-Perez, O. Gutierrez-Coronado, L. Sandoval-Ramirez, and M. M. Villasenor-Garcia. 2006. Dysregulation of the Th1/Th2 cytokine profile is associated with immunosuppression induced by hypothalamic-pituitary-adrenal axis activation in mice. Int. Immunopharmacol. 6:774-781.

Vogel, F. S., E. F. Flores, R. Weiblen, E. R. Winkelmann, M. P. Moraes, and J. F. Braganca. 2004. Intrapreputial infection of young bulls with bovine herpesvirus type 1.2 (BHV-1.2): Acute balanoposthitis, latent infection and detection of viral DNA in regional neural and non-neural tissues 50 days after experimental reactivation. Vet. Microbiol. 98:185-196.

Weber, P. S., S. A. Madsen, G. W. Smith, J. J. Ireland, and J. L. Burton. 2001. Pre-translational regulation of neutrophil L-selectin in glucocorticoid-challenged cattle. Vet. Immunol. Immunopathol. 83:213-240.

Weber, P. S., T. Toelboell, L. C. Chang, J. D. Tirrell, P. M. Saama, G. W. Smith, and J. L. Burton. 2004. Mechanisms of glucocorticoidinduced down-regulation of neutrophil L-selectin in cattle: Evidence for effects at the gene-expression level and primarily on blood neutrophils. J. Leukoc. Biol. 75:815-827.

Wesley, I. V., J. H. Bryner, M. J. Van der Maaten, and M. Kehrli. 1989. Effects of dexamethasone on shedding of Listeria monocytogenes in dairy cattle. Am. J. Vet. Res. 50:2009-2013.

Xia, C. Q., R. Peng, F. Beato, and M. J. Clare-Salzler. 2005. Dexamethasone induces IL-10-producing monocyte-derived dendritic cells with durable immaturity. Scand. J. Immunol. 62:45-54. 